CSR reporting practices and the quality of disclosure:

\title{
An empirical analysis
}

\section{Giovanna Michelon}

Associate professor of Accounting

University of Exeter Business School

Department of Accounting

Streatham Court

Rennes Drive

Exeter EX4 4ST, UK

E-mail: g.michelon@exeter.ac.uk

Tel.: +44 (0) 1392725668

Fax: +44 (0) 1392723210

\section{Silvia Pilonato}

Assistant professor of Accounting

Department of Economics and Management

University of Padua

Via del Santo, 33

35123 Padova, Italy

E-mail: silvia.pilonato@unipd.it

Tel. +390498274259

Fax. +390498274212

\section{Federica Ricceri*}

Associate professor of Accounting Department of Economics and Management

University of Padua

Via del Santo, 33

35123 Padova, Italy

E-mail: federica.ricceri@unipd.it

Tel. +390498273845

Fax. +390498274212

*Corresponding author 


\title{
CSR reporting practices and the quality of disclosure:
}

\author{
An empirical analysis
}

\begin{abstract}
Research on CSR disclosure points to an increasing lack of completeness and decreasing amount of credibility in the information reported, as well as concerns about overall reporting practices. The aim of this paper is to investigate the (ab)use of three CSR reporting practices: the use of standalone reports, assurance, and reporting guidance. These practices may be the outcome of a substantive approach to CSR undertaken to carry out duties of accountability to stakeholders, or conversely they could represent symbolic actions intended to portray corporations as genuinely committed to CSR. Thus, we investigate the use of these three practices in relation to disclosure proxies that capture the quality of disclosure along three different yet complementary dimensions: the content of the information disclosed (what and how much is disclosed), the type of information used to describe and discuss CSR issues (how it is disclosed) and the managerial orientation (the corporate approach to CSR). We find that, on average, companies that use these practices do not provide a higher quality of information, which we interpret as evidence of a symbolic use of these practices. Nevertheless, for those companies providing performance-related disclosures, we obtain limited evidence indicating that disclosures by GRI followers are more likely to be balanced, comparable and precise. Overall, our evidence supports increasing scepticism about the use of CSR reporting practices as tools used to enhance perceived accountability.
\end{abstract}

\section{Keywords:}

Accountability; Critical; Sustainability; Reporting practices; Disclosure quality; Legitimacy theory.

\section{Introduction}

Growing and widespread interest in corporate social responsibility (CSR) has helped generate the diffusion of a broad set of CSR activities by firms of all types. CSR has been investigated along a variety of lines of inquiry including strategic choices (emphasizing environmental goals achieved by firms), supply chain management or industry proposals (aiming to establish some forms of self-regulation, e.g. Hoffman et al., 2014; King and Lenox, 2000; Reid et al., 2009; Sharma, 2000), organizational approaches (providing an original focus on new forms of ecological culture and behaviours, or on examples of institutional entrepreneurship, e.g. Basu and Palazzo, 2008; Busch, 2011; Etzion and Ferraro, 2010; Forbes and Jermier, 2011), and sociopolitical strands (investigating networks and relationships among businesses, citizens and the 
natural environment, e.g. Bondy and Matten, 2011). Companies also appear to increasingly engage in disclosure related to their environmental and social impacts (KPMG, 2011; KPMG 2013), fostering accounting research on CSR reporting from a variety of perspectives and methodological approaches (e.g. Aerts et al. 2008, Cho and Patten, 2007; Cho et al., 2010; Cormier et al., 2005; Dhaliwal et al., 2011; Dhaliwal et al., 2012; De Villers et al., 2014; Mahoney et al., 2013; Malsch, 2013; O’Dwyer and Owen, 2005).

A critique of CSR reporting also has flourished in the social accounting literature (e.g. Milne and Gray, 2013 for a review). CSR reporting has been criticized for its lack of relevance and credibility (Husillos et al., 2011), and for its failure to impact sustainable development (Gray, 2010). Using a positivist approach, our study seeks to contribute to this critique by offering new insights concerning the complexity and quality of CSR disclosures and their relationship with the adoption of three CSR practices, namely the presence of a stand-alone report, the use of the Global Reporting Initiative (GRI) framework and the assurance of CSR information. We selected these three practices because a rich body of related literature has developed that provides contrasting evidence regarding the role they play in CSR accountability. More specifically, our motivation to further investigate such practices is fostered by the increasing debate over the lack of completeness and credibility of CSR information (Adams, 2004; Adams and Evans, 2004; Dando and Swift, 2003; Doane, 2000; Gray, 2010) and its potential benefits relative to investors and financial stakeholders (Bird et al., 2007; Cormier et al., 2005; Dhaliwal et al., 2012; Dhaliwal et al. 2014). We view this as important because despite the widespread popularity of these CSR practices, concerns have been raised as to whether their introduction and development is designed simply to suggest a positive image of the organization, being essentially one-sided and incomplete, or to communicate its effective commitment by recognising and discussing environmental and social challenges and problems.

This debate can be traced back to the double-edge "sword" of organizational legitimation theorized by Ashforth and Gibbs (1990), on which most social disclosure accounting research has 
drawn its understanding of legitimacy (Chen and Roberts, 2010). Under the substantive approach to corporate legitimacy, concrete changes in corporate actions are used to align organizational strategies and processes to social norms. Under the symbolic approach, practices emerge to positively influence stakeholders' perceptions, leading key stakeholders to mistakenly believe that the company is committed to societal expectations.

Relying on legitimacy theory, the paper explores whether these three CSR practices are used to indicate an effective commitment to CSR, and are thus associated with enhanced disclosure quality (substantive approach), or represent simply an attempt to construct an image of commitment that is designed to positively influence stakeholders' perceptions (symbolic approach). According to Hopwood (2009), companies may adopt disclosure strategies in order to construct a new, more legitimate image, reduce the number of questions asked, and retain a level of secrecy. Therefore, it is possible that such disclosures do not improve what is known about a company's objectives, activities and social and environmental impacts but rather serve to protect the organization from external pressure ${ }^{1}$

While there are studies that have considered other mechanisms as possible areas for substantive or symbolic initiatives (e.g. Rodrigue et al., 2013 look at governance mechanisms, and Berrone et al., 2009 examine firms' policies and actions), there has been relatively less research on whether specific CSR reporting practices (e.g., assurance, guidance and release of ad hoc standalone reports) are most consistent with a symbolic or substantive approach to CSR. Social accounting studies mainly frame CSR disclosure as a symbolic legitimacy tool (Cho and Patten, 2007; Patten, 2002), while more mainstream market-based research relies on agency theory and considers CSR disclosure to be a form of voluntary disclosure that is valuable to firms' stakeholders

\footnotetext{
${ }^{1}$ It is worthy to mention that this paper does not explore the motivations or implications of the diffusion of sustainability reporting as called for by some research (i.e. Thorne et al., 2014). Rather it takes the actual diffusion of CSR reporting practices among listed firms as its starting point and provides a deep and broad insight into the quality of the CSR information disclosed.
} 
and investors (Cormier and Magnan, 2007; Moser and Martin, 2012; Dhaliwal et al., 2012; Clarkson et al., 2008) ${ }^{2}$.

Couched within this debate, our paper empirically examines whether the use of a standalone report, the assurance of CSR information and the adoption of the GRI guidelines are associated with CSR disclosure quality. The novelty of our approach is two-fold. First, we develop a disclosure instrument that goes beyond more traditional measures, focusing on volume and/or frequency of disclosure and capturing a high level of resolution of meaning of CSR information (Beck et al., 2011). Second, we provide a detailed documentation of the information provided that allows us to consider multiple dimensions of analysis, including the corporate commitment to CSR. We consider three different yet complementary dimensions: the content of the information disclosed (what and how much is disclosed), the type of information used to describe and discuss CSR issues (how it is disclosed) and the managerial orientation (the corporate approach to CSR). We then combine these dimensions to measure disclosure quality, along the lines proposed by Beretta and Bozzolan (2004).

If firms use a substantive approach to CSR, we expect the three CSR practices to be associated with higher quality disclosures. Within this approach, disclosure would be the natural outcome of the corporation's use of a broader social and environmental management accounting system (Henri and Journeault, 2010) and therefore be informative, able to provide measurable information, disclosed in a way that helps users appreciate the social and environmental aspects of corporate activities as well as the underlying corporate commitment to CSR. On the other hand, if firms use a symbolic approach to CSR, we expect to find no association between CSR practices and the quality of disclosure.

\footnotetext{
${ }^{2}$ In this mainstream literature, CSR information affects the stock market valuation of firms' earnings (Cormier and Magnan, 2007), or it seems to provide value relevant information to investors about firm's performance (Dhaliwal et al., 2012) as well as to reduce the cost of equity capital (Dhaliwal et al. 2012). In a recent contribution, Cho, Michelon, Patten and Roberts (2012) criticize the recent wave of mainstream interest in CSR in that "the authors are either unaware of, or unwilling to acknowledge, the body of research that investigates both the early CSR reporting and, more generally, corporate social and environmental disclosure over the past three decades".
} 
Our findings, based on a sample of 112 UK companies over a three-year period $(2005,2006$ and 2007), suggest that issuers of stand-alone reports are likely to provide more disclosure than firms releasing CSR information in the annual report but not a greater quality of disclosure. Assurance and the use of the GRI guidelines are not associated with the quality or quantity of disclosure $^{3}$. We interpret this lack of significant association between CSR reporting practices and disclosure quality as evidence that these reporting practices are more likely to be undertaken as a symbolic approach to CSR, in line with increasing concerns in the social and environmental accounting literature that these practices are nothing more than a tool to manage corporate image, rather than a substantive improvement in the accountability process (e.g., Cho, Michelon and Patten, 2012; Hopwood, 2009; Merkl-Davies and Brennan, 2007; Moneva et al., 2006). We believe this study contributes to the critique of CSR reporting by adding new evidence that these CSR practices are developed within an institutionalization process (Larrinaga, 2014) and in line with the idea that they have become prone to "managerial capture" (Owen et al., 2000).

The remainder of the paper is organized as follows. The next section defines the conceptual framework, based on the legitimacy theory, and discusses the potential substantive vs. symbolic use of three CSR-related reporting practices, presenting our research questions. Sections 3 outlines the multidimensional disclosure framework used to capture the complexity related with the notion of (CSR) disclosure quality. Section 4 illustrates the research method and Section 5 presents the results. Finally, section 6 provides the contributions of the study and presents the conclusions.

\section{Conceptual framework}

Accounting researchers have suggested that CSR disclosure helps to resolve some of the problems of organizational legitimacy (Neu et al., 1998), because the voluntary reporting of social and environmental information helps maintain good relationships with relevant publics. Suchman defines legitimacy as the "generalized perception or assumption that the actions of an entity are

\footnotetext{
${ }^{3}$ We consider a disclosure quantity measure adjusted by the two main factors that literature has found to influence voluntary disclosure: industry and size.
} 
desirable, proper or appropriate" within a social system (Suchman, 1995, p. 574). This definition supports the focus on both the adoption of practices or policies able to influence the societal appraisal and disclosure as a means to change this perception, therefore increasing or decreasing firm's legitimacy (DiMaggio and Powell, 1983; Deephouse, 1996; Suchman 1995). According to this perspective, CSR disclosure and reporting practices take on an important role in the process of legitimacy acquisition because they may (or not) be useful to increase the stakeholders' knowledge about corporate activities and results achieved. Thus, while voluntary CSR activities are growing rapidly, controversy has arisen in the literature as to the merits of such initiatives (e.g., Ball and Craig, 2010; Burrit and Schaltegger, 2010; Cho et al., 2013; Cho, Guidry et al., 2012; Larrinaga, 2014; Lewis and Unerman, 1999; Milne, 2002; Neu et al. 1998; Nielsen et al., 2009). For instance, Bebbington et al. (2008) propose CSR reporting as a form of discourse intended to manage perceptions of the public and to response to perceived legitimacy threats. Larrinaga (2014) provides an insight into the question of how such reporting has become a "de facto" law for firms underlining a critique consistent with the idea that, while being a generally accepted activity, it is not providing credible information. Cho et al. (2010) find evidence that environmental disclosure is subject to impression management techniques even when it is reported in the annual report of firms and in a high litigation environment as the US. Other studies have raised doubts over the value of such initiatives for investors (Kolk at al., 2001) by stressing the role of voluntary social disclosures in annual report as an attempt to gain legitimacy following adverse publicity from the media (Kent and Zunker, 2013) or to shape impressions of the relevant publics (Neu et al., 1998). Some concerns about the credibility of sustainability reports are identified also by Amran et al. (2014), who focus on the (weak) role of the board of directors in upholding the sustainable development agenda through the reporting process.

Ultimately, this debate traces back to the double-edge "sword" of organizational legitimacy (Ashforth and Gibbs, 1990) and the two general approaches that organizations use to seek legitimacy: substantive management and symbolic management. Substantive management 
represents concrete, authentic changes in corporate actions intended to align organizational strategies and processes to social norms. Within the substantive approach, firms attempt to obtain legitimacy through changes in actions and policies, as a strategic response to external conditions; in sum, it should be critical for external public to " know much more about whether those changes in strategy also changed in action" (Hopwood, 2009p. 437). Symbolic management aims to positively influence stakeholders' perceptions of the firm, engaging in apparent actions that lead key stakeholders to believe that the company is committed to societal requirements (Ashforth and Gibbs, 1990). The objective, thus, is to portray the corporation as socially responsible, independently of whether it really is or not, creating an appearance of concern that does not translate into actual performance (Cho, Guidry et al., 2012; Patten, 2005). The symbolic approach is traced back to "the ceremonial conformity" (Meyer and Rowan, 1977), which consists of adopting "certain highly visible and salient practices that are consistent with social expectations while leaving essential machinery of the organization intact" (Ashforth and Gibbs, 1990, p. 181).

The growing diffusion of sustainability initiatives has fostered the development of studies based on the idea of substantive and symbolic CSR management. Specifically, using the lenses of the double-edge of organizational legitimacy, Rodrigue et al. (2013) examine the association between environmental governance and environmental performance. They posit that substantive practices would bring changes in organizations, translating into changes in environmental performance, whereas symbolic practices would portray organizations as environmentally committed without making meaningful changes to their operations (and thus performance). They interpret the absence of any significant association between environmental governance and performance as consistent with the idea that environmental governance is executed predominantly as part of a symbolic approach to the management of stakeholder perceptions, having little substantial impact on organizations. Berrone et al. (2009) explore a set of sustainability related activities, defining symbolic those whose final goal is to influence societal perceptions of the company by using more obvious, overt actions to obtain legitimacy (such as participation in 
voluntary environmental programs, formal communications and campaigns, or the establishment of an environmental board committee). In contrast, substantive actions require significant changes in core practices, which could culminate in real improvements in firm's performance and ultimately increase a firm's legitimacy (pollution prevention strategies, environmental innovations, etc.). Mahoney et al. (2013) attempt to understand whether firms issue a stand-alone CSR report as a substantive signal of concern for environment or as a green-washing initiative. Along similar lines, Boiral (2013) examines the extent to which sustainability reports can be viewed as a simulacrum used to camouflage real sustainable issues by focusing on the quality of information and the adoption of reporting standards (GRI).

Whether CSR practices are used under a substantive or symbolic approach is therefore still an open question. Within a substantive approach, CSR disclosure would be considered the outcome of a sense of accountability to stakeholders, driven by a genuine interest in enhancing transparency. Under this approach, companies undertake various reporting practices, such as the use of standalone reports, reporting guidelines, and assurance of the information disclosed to enhance the quality of the information communicated, ensure its reliability, and enhance the stakeholders' engagement process. Unerman et al. (2007, p. 3) claim that "just as conventional management and financial accounting has been a powerful tool in the management, planning, control and accountability of the economic aspects of organizations, broader techniques of sustainability accounting and accountability have the potential to be powerful tools in the management, planning, control and accountability of organizations for their social and environmental impact. Or, in other words, for the social and environmental in addition to the more conventional economic sustainability of the organization." Recent studies (Cormier et al., 2005; Moser et al., 2012; Dhaliwal et al., 2011; Dhaliwal et al., 2012) provide evidence on the relevance of CSR information for the market. For instance, reports seem to provide value relevant information to investors about firm's financial performance (Dhaliwal et al., 2012) or to reduce the cost of equity capital (Dhaliwal et al., 2012). In this perspective, CSR disclosures would be addressing shareholders demand for 
information and monitoring. Moreover, because CSR reporting is non-mandatory, Lewis and Unerman (1999) claim that it can potentially reflect the ethical values of the company and their change over time better than mandatory disclosure, over which the managerial discretion is lower. Some companies fulfil their social obligations by doing what is considered morally right and use CSR to carry out their duties related to accountability to stakeholders. Spence (2009) claims that social accounting and reporting practices like corporate self-reporting can even be involved in the democratic development of an effective social responsibility policy, underscoring the main role of the "civil society" in supporting these changes. In this case, social reporting practices should concern how the company addresses real social and environmental problems, increasing transparency and then enhancing democracy (Brown, 2009; Spence, 2009) ${ }^{4}$. In the same vein, Clarke (2007, p. 241) explains that "what is absolutely critical is the accuracy of corporate disclosure regarding CSR performance" and Hopwood (2009, p. 438-439) states the "importance of looking at actions and consequences as well as just aims and intentions". Moreover, in discussing the "decision usefulness" of CSR information, Chauvey et al. (2013, p. 11) point to comparability as a beneficial characteristic, which "makes it possible, within a pre-defined report perimeter, to assess the evolution of data over time, or to evaluate them consistently and objectively with those of other companies." From this literature review, it follows that a substantive approach to CSR reporting implies that reporting practices would be used to enhance the quality of the information disclosed.

Within a symbolic approach to CSR reporting, the disclosure may be used to portray the corporation as "committed" (see Cho, Guidry et al., 2012; Patten, 2005), and reporting used to facilitate the construction of an inaccurate company image (Hopwood, 2009). As a mean of communication, CSR reporting is exploited as an opportunity to camouflage corporate activities, obfuscate negative performance (Cho et al., 2010) and to project corporate images detached from

\footnotetext{
${ }^{4}$ Thomson and Bebbington (2005: 527) argue that CSR reporting "should 'pose problems' about real world situations in order to help stakeholders develop a critical view of their reality. If this was to happen, social and environmental reporting would become part of a political act, not a simple communication conduit." This argument is beyond the scope of our investigation.
} 
reality (Boiral, 2013). Therefore, from this perspective, CSR disclosure provides firms with a way to influence external perceptions and to build or maintain their legitimacy to operate (Suchman, 1995; Dawkins et al. 2011). In fact, organizational legitimacy is often constructed and maintained through the use of symbolic actions (Dowling and Pfeffer, 1975; Elsbach, 1994; Neu et al., 1998) that form part of the organization's public image. Dowling and Pfeffer (1975, p. 127) argue, for example, that "the organization can attempt, through communication, to become identified with symbols, values, or institutions which have a strong base of social legitimacy." In contrast to CSRreporting practices that are undertaken with a substantive approach, the symbolic approach is the source of concerns that reporting practices have become (ab)used, that is, prone to "managerial capture." By taking control of the reporting process, managers disseminate information only if it improves the corporate image, rather than seeking transparency and accountability to stakeholders (Owen et al., 2000). Therefore, in a symbolic use of CSR-reporting practices, disclosure would translate in the diffusion of a great volume of "empty" sentences or replicate boiler-plate information, in a way that offers little to enhance stakeholders' knowledge about corporate activities and their impact. In other words, although reports cover many topics (e.g., employees, customers, environment), thus increasing the quantity or extensiveness of disclosure, all of this information may not necessarily inform stakeholders about a firm's actual activities. As literature claims (Boiral, 2013; Hopwood, 2009) companies may even adopt modes of reporting that reduce what is known about a company and its environmental activities, contrary to the principles of completeness and transparency.

These two opposing perspectives to CSR reporting pose an important research question because, despite the broad diffusion of CSR reporting practices (stand-alone reporting, CSR reporting guidelines, and assurance over the information disclosed), companies may provide more but not enhanced social and environmental information.

\subsection{Stand-alone reporting}


CSR reporting has evolved from information on the corporate environmental and social policies included in annual reports to stand-alone combined reports that include social, environmental, and economic/financial information (Buhr, 2002; Cho, Michelon and Patten, 2012; Milne and Gray, 2007). Recent trends in environmental disclosure and reporting practices suggest a largely increasing number of stand-alone reports, which include social, environmental and economic/financial information (Cho et al. 2011). The issuance of such sustainability reports has now become almost a standard amongst the world's largest corporations. Colbert and Kurucz (2007) report that 68 per cent of the 250 largest multinational corporations had adopted CSR reporting by 2005. The most recent KPMG Survey (2011) shows that 95 per cent of the Global Fortune 250 companies report their CSR activities and that reporting overall (in the 34 companies surveyed) has increased by 11 per cent since 2008 to 64 per cent.

According to some authors, what particularly makes these stand-alone reports remarkable is that they represent a clear engagement of corporations with the increasingly critical issues of environmental and social responsibility, as well as businesses sustainability (Gray and Herremans, 2011). In many studies, the issuance of a standalone report is seen as a proxy tout court of CSR disclosure quality, potentially providing significant information for investors to assess firms' overall CSR performance (Dhaliwal et al., 2012; Dhaliwal et al., 2014). Other research provides support to the relevance of CSR stand-alone reports in that they appear to signal a superior firms' commitment to social and environmental issues (Mahoney et al., 2013).

Nevertheless, the social accounting literature has mostly critically evaluated the shortcomings of CSR reporting in that - while accountability is very obviously needed - it is not clear if these voluntary reports are actually increasing accountability, as opposed to increasing the appearance of such accountability (Gray, 2002; Gray and Herremans, 2011). Scholars have expressed reservations about the aim of these reports as substantive CSR reporting practices (Cooper and Owen, 2007; Gray et al., 1988; Moneva et al., 2006; Tinker et al., 1991). Many critics of the sustainability accounting trend see the reports as little more than public relations tools 
designed to maintain the approval of crucial stakeholders for the survival of the business (Unerman et al., 2007) or to manage the political and media visibility (Thorne et al., 2014). Given that the use of a stand-alone report is voluntary, there are significant opportunities for using it as a symbolic practice (e.g., Merkl-Davies and Brennan, 2007). Buhr (2002, p. 17) underscores how stand-alone reports can be used as a mechanism to fulfil accountability relationships or as a "slick public relations device to stave off threats (legislative, consumer-oriented and otherwise) to the firm." While Buhr's findings suggest that the environmental report is generally used as a tool to increase organizational transparency, she highlights how some companies pursue other purposes, such as a strategy of symbolic legitimization.

Based on the conceptual framework and debate discussed above, we posit the following research question:

\section{RQ1: Is the presence of a stand-alone report associated with disclosure quality under a substantive or symbolic approach?}

\subsection{GRI guidelines}

The literature addresses another potentially abusive CSR-reporting practice: the use of CSR reporting guidelines. The GRI reporting framework is widely acknowledged as a leader in the international standardization of sustainability reporting (Bebbington et al., 2012; Gray, 2010; Mahoney et al., 2013). It is also considered the primary example of sustainability reporting, as it has wide application in multi-national firms that operate in a variety of industries (Joseph, 2012). Firms' emphasis on the role of the GRI guidelines has been confirmed by recent studies (Mahoney et al., 2013). Firms that follow the GRI reporting framework appear to have higher levels of commitment to CSR than do firm that do not follow it. Even so, authors criticize the GRI framework from a theoretical point of view because the sustainability principle seems to be widely 


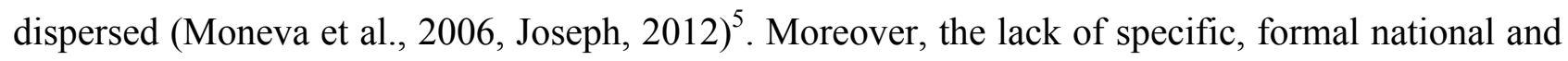
international regulations seems to allow companies much flexibility in how they carry out their social and environmental reporting activities and allows them to use guidelines in a biased way (Freedman, 1998; Moneva et al., 2006; Sutton and Arnold, 1998). A recent study on the use of CSR reporting templates (such as GRI) claims that companies may increase their symbolic performance by being able to "tick more GRI boxes", therefore increasing the measured volume of their reporting. Indeed such greater measured volume may be not necessarily indicative of management intent regarding social and environmental issues (De Villers et al., 2014). Perhaps, firms' voluntarism in using the GRI should be supported by external factors, such as forms of regulation or inclusion of professional agencies in the firms' communication process (Joseph 2012).

Given the debate over the proper consequences of GRI adoption towards reporting quality, we pose the following research question:

RQ2: Is the use of GRI guidelines more associated with disclosure quality under a substantive or a symbolic approach?

\subsection{Assurance of CSR information}

Another important topic discussed in the research on CSR reporting is the level of confidence in and transparency of the information reported (Adams et al. 2004; Dando and Swift, 2003; O’Dwyer and Owen, 2005). One of the key elements used to ensure credibility of sustainability reports is external assurance, even if per se it is not enough to avoid criticism regarding such credibility (Adams et al. 2004). Many of the concerns highlighted by relevant literature refer to some forms of a credibility gap: for example, Swift and Dando (2000) and Dando and Swift (2003) point to a lack of technical competencies and assurance-provider independence. Other studies also have suggested

\footnotetext{
${ }^{5}$ The GRI has recently been object of severe criticism because the reporting principle known as the "sustainability context" is not included in the release of the new Sustainability Reporting Guidelines G4. According to its proponents, without this principle "sustainability reporting isn't asking itself this fundamental question" [Guardian Sustainable Business Blog: http://www.guardian.co.uk/sustainable-business/blog/what-is-purpose-of-sustainability-reporting, accessed on Friday May 24, 2013]. This vein of criticism is also beyond the scope of our investigation.
} 
the importance of rigorous independent verification processes (Adams et al. 2004; Ball et al., 2000; O'Dwyer and Owen, 2005, Zorio et al. 2013 BSE) in order to provide adequate assurance to stakeholders regarding the credibility, completeness, and materiality of the social and environmental information reported.

The independence of the assurer, the content of the assurer's report, and the nature of what is being assured are all important considerations in establishing credibility, and the literature's suggestions for the role of third parties tends to be based on a consultancy model that supports the management activity rather than on an independent assurance model that reinforces transparency (Ball et al., 2000). O'Dwyer and Owen (2005) evaluate the extent to which the contents of assurance statements address the main elements of the most recent assurance guidance released by international bodies such as AccountAbility $(2003,1999)$, the Fédération des Experts Comptables Européens (2002), and the Global Reporting Initiative (2002). They find some improvement in the independence of the evaluation process and in the focus on firms' performance. Considering that these studies investigate samples of best practices in CSR reporting, doubts remain about the ability of independent assurance practices to enhance the transparency and completeness of and public confidence in CSR reports. Moreover, Owen et al. (2000) claim that, without real change in corporate governance structures, social audits amount to little more than another management fad or a skillfully controlled public relations exercise. In particular they investigate the integration of social and environmental reporting and auditing procedures, underlining that quantitative data and indicators are generally lacking in social reports, but that they constitute a necessary initial step to improving credibility and comparability of the information reported. Furthermore, based on a sample of US firms that issued stand-alone reports in 2010, Cho et al. (2013) find that assurance is not associated with higher market value for companies that issue such reports, but that companies with assurance on their CSR reports are more likely to be included in the Dow Jones Sustainability Index and are perceived to be more "green", based on Newsweek's 2011 ranking of "the greenest companies in America." The findings by Cho et al. (2013) support the argument that the benefits of 
assurance are limited to perceptions of the companies' social and environmental image, which is in line with the idea that assurance is a symbolic practice. Wong and Millington (2014) examine the perceptions of diverse stakeholder groups towards corporate social assurance. They discuss that emerging pressures from stakeholders raise the importance of assurance, and that stakeholders clearly prefer specialist assurors rather than financial auditors because the perception of independence and subject expertise - rather than competence in auditing procedures - is considered key to the trustworthiness of assurors.

Notwithstanding the risk of "managerial capture", some studies affirm that, if the assurance process focuses on the needs of corporate stakeholders and it is conducted using assurance principles and guidelines, voluntary assurance of CSR information will increase the completeness and credibility of the information (Adams et al., 2004); other studies highlight the fairly acceptable quality of the assurance reports themselves (Manetti and Beccatti, 2009; Zorio et al., 2013) or suggest that assurance allows stakeholders to be increasingly involved in the reporting process because it changes managers' attitudes toward them (Edgley et al., 2010). Therefore, because the assurance practice could provide real changes in a firm's processes, it may represent a substantive reporting practice.

Given the debate over the use of assurance practice, we investigate the following research question:

RQ3: Is the assurance of CSR information more associated with disclosure quality under a substantive or symbolic approach?

\section{Disclosure framework: capturing the quality of CSR disclosure}

Disclosure frameworks adopted by previous studies (Cho and Patten, 2007; Cormier and Magnan, 2003; Patten, 2002) have been built primarily on a checklist of items that capture the amount and variety of disclosure, but we argue that this approach does not sufficiently capture the complexity of the information that management can communicate on the social and environmental 
impact of their corporate activities nor on the important criteria for determining the quality of CSR information (GRI, 2006).

Most CSR-reporting studies have evaluated CSR disclosure based on the amount of space allocated to disclosure and on the theme of the information provided. As Chauvey et al. (2013) observe, while both the amount ("how much") and the themes ("what") of CSR disclosure are potentially important for firm managers and report users, they do not take into account other important dimensions that characterize the information disclosed. As a consequence, a number of studies have modified the traditional content analysis framework and scoring method in an attempt to improve how the variety and multidimensionality of the informational items are captured ${ }^{6}$. With the exception of Chauvey et al. (2013), who focus on disclosure-quality measures inspired by the accounting principles of relevance, comparability, verifiability, clarity, and neutrality, and Patten and Zhao (2014), who look at the presence of performance disclosure, these extant studies are not able to capture the quality of the disclosure ${ }^{7}$.

Following Beretta and Bozzolan (2004) we contend that the quality of disclosure "depends on both the quantity of information disclosed and on the richness offered by additional information" (p. 266), whereas richness of CSR information could be thought as the extent to which information help users appreciate the social and environmental impact of corporate activities and infer management approach to CSR. For example, UNEP/SustainAbility reporting guidelines (1996) present a clear description of how the effects and information on performance benchmarked against targets can be beneficial. Beretta and Bozzolan (2004) highlight the importance of semantic properties of information, in other words not only how much but also what is disclosed and how. Along the lines of Beretta and Bozzolan (2004), Beck et al. (2011, p. 210) claim that "greater

\footnotetext{
${ }^{6}$ Dimensions that were investigated included measurability, that is, distinguishing and weighting differently monetary, quantitative, and qualitative information (e.g., Al-Tuwaijri et al., 2004; Choi, 1999; Wiseman, 1982), and whether the disclosures were descriptive, vague, or immaterial (e.g., Hughes et al., 2001).

${ }^{7}$ Other studies, such as Cho et al. 2010, Cho Michelon and Patten, 2012 rely on disclosure proxies aiming at capturing the degree of impression management in CSR information, such as biased language and graph distortion.
} 
information diversity reflects an organization's awareness of its impact on a wider scale" and call for an instrument able of capturing a high level of resolution of meaning.

To overcome the limitations of traditional classification schemes and to incorporate in our analysis a concept of quality of CSR information, we adapt the framework proposed by Beretta and Bozzolan (2004) for risk disclosure to CSR disclosure. Their framework allows to capture a great number of quantitative and qualitative features concerning a specific kind of voluntarily disclosed information, such as that about firms' risks. In line with their work, we propose a framework that captures three different yet complementary dimensions: the content of the information disclosed (what and how much is disclosed), the type of measures used to describe and discuss CSR activities (how it is disclosed) and the managerial orientation (the corporate approach to CSR).

We build the CSR items measuring the content of disclosure by relying on the G3 guidelines (GRI, 2006), producing a content scheme that identifies 10 environmental information items and 22 social information items that suggest the themes of disclosure. As for the semantic properties of disclosure, first we propose that CSR disclosure is enriched by the way in which CSR activities are qualified and quantified (accuracy of information), in other words whether the CSR activities are measured and described in qualitative, quantitative or monetary terms. Second, we consider another dimension: the managerial orientation. Following Beretta and Bozzolan (2004), we consider managerial orientation to reflect both the time orientation of the information disclosed (forward or backward looking) and the boilerplate vs. committed approach to CSR (disclosure can be general information that does not help readers understand the impact of corporate activities, thus suggesting a boiler approach, or provide specific information about objectives and results, providing readers with insights on the underlying commitment of the organization, thus suggesting a committed approach). Table 1 summarizes the classification scheme. 


\subsection{The dimensions for the analysis of CSR disclosure}

Beretta and Bozzolan (2004) point out that there are two aspects with regards to the quantity of information that have to be balanced: the absolute number of items disclosed and its weight in the overall information being provided. In line with their approach, we consider both a relative quantity index and a density index.

We measure quantity $\left(R Q T_{\mathrm{i}}\right)$ as the standardized residuals of an OLS regression model of disclosure using size and industry as independent variable (Beattie et al., 2002): $D i s c_{i}=\beta_{0}+$ $\sum_{j=1}^{k} \beta_{j} I N D_{j}+\beta_{k+1} S I Z E$. This index takes greater values when a company discloses more information than the average of companies belonging to the same industry, adjusted by size (measured as the natural logarithm of sales). In order words, the disclosure quantity measure is adjusted by two external factors that have been persistently found to influence the level of disclosure:

(1) $R Q T_{i t}=D i s c_{i t}-\widehat{D_{l S C}}$, where $R Q T_{i t}$ is the relative quantity index for company $i$ in year $t, D_{i s c_{i t}}$ is the observed level of disclosure for company $i$ in year $t$ and $\widehat{D_{l S C}}$ is the estimated disclosure level for company $i$ in year $t$.

Under the clarity principle in the G3.1 guidelines, GRI recommends that the report shall contain the level of information required by stakeholders but avoid excessive and unnecessary detail. Beretta and Bozzolan (2004) also argue that the effectiveness of narrative reporting is associated with the writing styles and the relevance of information is affected by "how much it is diluted into the mass of other pieces of information disclosed" (p. 272). From a company's perspective, and somewhat similar to the risk disclosure analysed by Beretta and Bozzolan (2004), diluting CSR information in a long document as a stand-alone CSR report may serve to communicate relevant information but in a way that is hard for the user to find or to anyways obfuscate relevant information and divert attention (Merkl-Davies and Brennan, 2007; Cho et al., 2010). We thus define density $\left(D E N_{i t}\right)$ of CSR information as the ratio between the number of sentences in which CSR information is provided over the total number of sentences contained in the 
stand-alone report or CSR section of the annual report. This ratio varies between 0 and 1 , where values close to 1 are associated with less dilution of relevant information in the document analysed: (2) $D E N_{i t}=\frac{1}{k_{i t}} \sum_{j=1}^{k_{i t}} C S R_{i j t}$, where $D E N_{i}$ is the density index for company $i$ in year $t$, $\mathrm{k}_{\mathrm{it}}$ is the number of sentences in the document analysed for company $i$ in year $t$ and $C S R_{i j t}=1$ if the sentence $\mathrm{j}$ in the document analysed for company $i$ in year $t$ contains CSR information and $\operatorname{CSR}_{i j t}=$ 0 otherwise.

To measure the accuracy of information, we consider the type of information used in CSR disclosure. Similar to Wiseman (1982), we assign monetary disclosures 3 points, quantitative but non-monetary disclosures 2 points, and qualitative disclosures 1 point. The accuracy of information index $\left(A C C_{i t}\right)$ is determined as the ratio between the sum of the weighted value of all the sentences that contain CSR information over the number of CSR sentences contained in the report (or in the section of the annual report that is dedicated to CSR). This final measure ranges from 1 to 3 , where a value close to 1 implies that the information disclosed is mainly qualitative, while a value close to 3 means that most of the information is mainly expressed in monetary terms.

(3) $A C C_{i t}=\frac{1}{n_{i t}} \sum_{j=1}^{n_{i t}}\left(w * C S R_{i j t}\right)$, where $A C C_{i t}$ is the accuracy index for company $i$ in year $t$, $n_{i t}$ is the number of sentences containing CSR information in the document analysed for company $i$ in year $t, C S R_{i j t}=1$ if the sentence $\mathrm{j}$ in the document analysed for company $i$ in year $t$ contains CSR information and $C S R_{i j t}=0$ otherwise, $w=1$ if the sentence $\mathrm{j}$ in the document analysed for company $i$ in year $t$ is qualitative, $w=2$ if the sentence $\mathrm{j}$ in the document analysed for company $i$ in year $t$ is quantitative, $w=3$ if the sentence $\mathrm{j}$ in the document analysed for company $i$ in year $t$ is monetary.

The fourth disclosure index is the managerial orientation. In its spirit, it is similar to the outlook profile measure proposed by Beretta and Bozzolan (2004), but it is adapted to the specificities of CSR disclosure and intends to provide insights on the corporate approach to CSR. Prior research (e.g., Adams 2004) suggests that, in order to discharge accountability, companies' 
disclosure should be complete. Bouten et al. (2011) refer to the concept of "comprehensiveness" of disclosure: companies should not only report their intentions, but also their actions and subsequent performance. Nevertheless, according to Hopwood (2009), environmental disclosure tends to be more focused on strategies, plans, and intentions than on results. CSR disclosure can communicate very standardised statements (boilerplate information) about general expectations concerning the future and context or policies and programs in place or rather provide stakeholders with objectives and goals the company wants to pursue together with an account of the results and outcomes of actions taken to meet stakeholders concerns. The managerial orientation of CSR disclosure can thus be classified along the time orientation and the boilerplate vs. committed approach as follows:

\begin{tabular}{|l|l|l|}
\hline Managerial Orientation & Forward Looking & Backward Looking \\
\hline Boilerplate approach & $\begin{array}{l}\text { Context - Expectations - } \\
\text { Hypotheses }\end{array}$ & $\begin{array}{l}\text { Policies, initiatives and } \\
\text { strategies }\end{array}$ \\
\hline Committed approach & Objectives and goals & $\begin{array}{l}\text { Results and outcomes of } \\
\text { actions }\end{array}$ \\
\hline
\end{tabular}

The index proposed $\left(O U T_{i t}\right)$ is determined as follows:

(4) $M A N_{i t}=\frac{1}{n_{i t}} \sum_{j=1}^{n_{i t}}\left(O B J_{i j t}+R E S_{i j t}\right)$, where $M A N_{i}$ is the managerial orientation index for company $i$ in year $t, n_{i t}$ is the number of sentences containing CSR information in the document analysed for company $i$ in year $t, O B J_{i j t}=1$ if the sentence $\mathrm{j}$ in the document analysed for company $i$ in year $t$ contains CSR information on goals and objectives and $O B J_{i j t}=0$ otherwise, $R E S_{i j t}=1$ if the sentence $\mathrm{j}$ in the document analysed for company $i$ in year $t$ contains CSR information on results and outcomes and $R E S_{i j t}=0$ otherwise.

Following Beretta and Bozzolan (2004), we standardise each of the four indexes to avoid a scale effect (so that each index ranges between 0 and 1), and we further compute a synthesis of the four indexes using the simple arithmetic mean as follows: 
(5) $\quad$ Quality $_{i t}=\frac{1}{4}\left(R Q T s_{i t}+D E N s_{i t}+A C C s_{i t}+M A N s_{i t}\right)$, where $R Q T s_{i t}$ is the standardised relative quantity index, $D E N s_{i t}$ is the standardised density index, $A C C s_{i t}$ is the standardised accuracy index and $M A N s_{i t}$ is the standardised managerial orientation index.

Table 2 summarizes the disclosure variables.

Insert table 2 about here

\section{Research method}

The analysis is conducted on firms listed on the London Stock Exchange for the years 20052007. We investigate companies listed in the UK because the literature has recognized this country's high level of experience in social (or ethical) and environmental reporting (Adams et al. 1998; Beck et al., 2011; Gray et al., 1995; Kolk et al., 2001). For example, in their research on corporate social reporting practices in six western countries, Adams et al. (1998, p. 16) claim that the UK stands out "ahead of the other countries we studied." Kolk et al. (2001) explain that, among the European firms included in the Fortune Global 250, UK companies present the most voluntary environmental reports. Other studies that have investigated only the UK (Brammer et al., 2006; Brammer and Pavelin, 2004; Gray et al., 1995) point out different motivations for the high level of social and environmental disclosure, such as the long history of trade union involvement, the ethical investment movement, the ACCA reporting award scheme, and significant differences in cultural values in the UK, the last of which also influenced the national accounting system (Adams and Kuasirikun, 2000; Adams et al., 1998; Bebbington et al., 2012). We choose these three years because we want to investigate CSR disclosure behaviours during a time in which several events might have increased societal pressure over CSR, thus increasing the "demand" for more disclosures on the social and environmental impacts of corporate actions.

In order for a firm to be included in the sample, the following requirements had to be met for all the three-years period (2005-2007): 
1) Firms are continuously listed on the London Stock Exchange

2) Firms have a stand-alone CSR report or annual report available for download either from the corporate website or Corporate Register

3) Control data is available.

We end up with a sample of 112 unique firms for which we have three years of observation. For each firm, we analyse the CSR disclosure contained in the sustainability or CSR reports, and when such report is not available, we look at the CSR or sustainability section in the annual report (all firms in our sample have a specific section in the annual report dedicated to CSR or sustainability). We choose content analysis, a methodology widely adopted in disclosure studies, to capture CSR disclosure. Following Krippendorff (2004), we organize our data collection into three phases. First, we define the recording unit as single sentences ${ }^{8}$ because they are generally considered more reliable than pages or paragraphs. Second, we set a coding procedure to capture the disclosure of CSR information. In this procedure, the sentences of the analysed reports are counted and then each sentence is assigned a score of 0 if it provides no information on any CSR-themed item and a score of 1 if it contains some information on CSR. Third, when a piece of CSR-themed information is identified, it is coded into the CSR disclosure framework according to the content it refers to (one of the 32 themes of disclosures defined by the G3 guidelines), the managerial orientation of the disclosure (expectations and context, programs policies and initiatives, objectives and goals, results and outcomes), and its characteristics (qualitative, quantitative, or monetary). Two researchers (one author and one research assistant) first performed a pilot test of the coding activity. Based on the evidence collected in the pilot test, all the authors and the research assistant discussed and defined a list of identification and classification rules to supplement the disclosure scheme. To avoid inter$\operatorname{coder}^{9}$ reliability problems, the research assistant carried out all the coding.

Table 3 provides an example of the output of the coding process.

\footnotetext{
${ }^{8}$ When one sentence referred to more than one thematic area, we coded the first one mentioned. If a sentence contained both quantitative and monetary information, we coded it as monetary.

${ }^{9}$ While using one coder may avoid inter-coder reliability, it also constitutes a limitation because multiple coders may assure more accuracy than one coder.
} 
Insert Table 3 about here

\subsection{Independent and control variables}

Table 4 summarises the independent and control variables considered in this study. Stand-alone is a dummy variable that equals 1 if the company provides a stand-alone CSR report and 0 if CSR information is reported in a specific CSR section of the annual report. Assurance is a dummy variable that equals 1 if there is an assurance statement and 0 otherwise. GRI is a dummy variable that equals 1 if there is a self-declaration of adherence to the GRI guidelines and 0 otherwise.

\section{Insert Table 4 about here}

Our multivariate analyses include a control for size because size has persistently been found to be significantly and positively associated with disclosure, suggesting that larger companies make more disclosures (Hackston and Milne, 1996; Patten, 1992, 1991). We measure size as the logarithm of total sales (Size). We further control for membership to environmentally or socially sensitive industries (ESSI). Following Brammer and Millington (2005), we classified firms from the extractive (mining and petroleum), chemical, paper, pharmaceutical, alcoholic beverages, and defense industries as those that face greater social exposure than companies in other industries. Based on prior studies that focus only on environmental disclosure (e.g., Cho and Patten, 2007; Freedman and Patten, 2004; Freedman and Wasley, 1990), we classified companies from the chemical, mining, metals, paper, petroleum, and utility industries as environmentally sensitive. Previous literature also finds a relation between CSR disclosure and CSR performance, although the evidence on the sign of this association is mixed (e.g. Al-Tuwaijri et al., 2004; Clarkson et al. 2008, Cho and Patten, 2007; Mallin et al. 2013; Patten, 2002). Thus, we further control for corporate 
social performance $(C S P)$ by retrieving data from Thomson Reuters' ASSET4 ${ }^{10}$. We measure corporate social performance as the average between the Social and Environmental Pillar scores provided by ASSET4 $4^{11}$. Finally, all multivariate regressions are run using year fixed effects.

\section{Empirical evidence}

\subsection{Descriptive results}

Table 5 summarizes the distribution of the reporting practices in the period of observation (Panel A) and the distribution of the reporting practices with respect to each other (Panel B). In particular, $55.35 \%$ of all observations have a CSR stand-alone report, 30.36\% provide assurance over CSR information and only $17.86 \%$ of observations follow the GRI guidelines. It is worthy mentioning that $4.46 \%$ of the observations provide assurance of their CSR information even when it is not reported in a stand-alone report, but only $0.89 \%$ of observations release CSR information in accordance to GRI when it is not reported in a stand-alone report. Finally, the overlap between Assurance and GRI is present in $13.39 \%$ of the observations, whereas only $4.46 \%(16.96 \%)$ of observations release CSR information in accordance with GRI (with assurance) but do not have external assurance (do not follow GRI).

Insert Table 5 about here

Table 6 provides descriptive statistics for disclosure and independent variables for the period of observation. On average, firms report 116 sentences with CSR information over a relatively high number of total sentences (318), which suggests that most of the sentences making up the documents do not report relevant CSR information (at least with respect to the disclosure items used

\footnotetext{
${ }^{10}$ This measure of social and environmental performance captures performance at a very broad level and thus bears some limitations. Nevertheless, as it is employed as a control variable, it should not invalidate our analysis.

${ }^{11}$ Typically, data for environmental performance would include information on emission reduction such as $\mathrm{CO} 2$ and other gases emissions, biodiversity protection, waste recycled, pollution controversies, etc.; product innovation such as footprint reduction, environmental R\&D expenditure, environmental labels, etc.; and resource reduction, such as total material use, energy use, water recycled, etc. Social performance would encompass data on employees such as turnover, accidents, injury rates, training hours, women, etc.; community involvement such as cash and in-kind donations, lending, political contributions, employee voluntary work; product responsibility such as quality certifications, social labels, controversial products such as tobacco, alcohol, etc.
} 
in this study). On average each document analysed had 25 pages, the maximum of 249 being registered for Centrica, in year 2006. In general most of the sentences analysed communicate qualitative information while an average of only $11.9 \%$ and $4.2 \%$ are respectively quantitative and monetary. Finally, when it comes to the management approach to CSR, the managerial orientation dimensions indicate that - on average - most of the sentences report more information on general expectations and initiatives over the future than on explicit objectives (respectively $38.1 \%$ vs. 3.2\%) and on programs and initiatives developed rather than results and outcomes of firm's plans (respectively $47.8 \%$ and vs. $10.9 \%$ ).

Insert Table 6 about here

Table 7 presents univariate correlation coefficients, which indicate no relevant multicollinearity issues in the variables included in our models ${ }^{12}$. It is important to mention that while the relative quantity index $(R Q T S)$ is positively related with total disclosure, the other dimensions of quality (density - DENs, accuracy - ACCs and managerial orientation - MANS) are not correlated with total disclosure. All the pair-wise correlation coefficients between the disclosure indexes and independent variables are significant (with the exception of the correlation between GRI and accuracy which is not significant). It is worthy to note that all reporting practices (CSR report, Assurance, and GRI) are significantly and negatively associated with the standardised density index (DENs) suggesting that - despite the fact these practices are correlated with more information (the correlation coefficients between reporting practices and RQTs are significant and positive), they are also more likely to be diluted with unnecessary information. Finally, all the indexes are correlated significantly and positively with corporate social performance with the exception of accuracy

\footnotetext{
${ }^{12}$ In order to test for multicollinearity, we performed the Variance Inflator Factor (VIF). A maximum VIF value in excess of 10 is frequently taken as an indication that multicollinearity may be influencing the least square estimate. In our case, the largest VIF is 1.6 , so multicollinearity among the predictor variables is not a problem.
} 
(positive correlation coefficient yet not significant) and density (negative and significant correlation coefficient).

Insert Table 7 about here

\subsection{Multivariate results}

We perform our multivariate analysis using the following model:

Disclosure $_{i t}=\mathrm{a}_{1}+\mathrm{B}_{1} \mathrm{CSR}$ Report $_{\mathrm{it}}+\mathrm{B}_{2}$ Assurance $_{\mathrm{it}}+\mathrm{B}_{3} \mathrm{GRI}_{\mathrm{it}}+\mathrm{B}_{4}$ Size $_{\mathrm{it}}+\mathrm{B}_{5} \mathrm{CSP}_{\mathrm{it}}+\mathrm{B}_{6} \mathrm{ESSI}_{\mathrm{it}}+\mathrm{e}_{\mathrm{it}}$

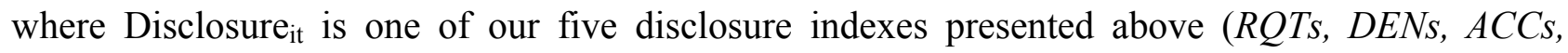
MANs, Quality) and summarized in table 2. All the other variables are defined in table 4.

Each OLS regression is run with robust standard error clustered at the firm level and using year fixed effects. Results are presented in Table 8.

Insert Table 8 about here

The use of a stand-alone report is positively associated with the standardised relative quantity index $(R Q T s)$ and negatively associated with the standardised density index (DENs) but not significantly associated with accuracy $(A C C s)$ or managerial orientation $(M A N s)$ measures. It is also not significantly associated with the overall quality index. The presence of assurance of CSR information and the adoption of the GRI guidelines are not significantly associated with any of our disclosure indexes.

In other words, on average, the presence of a stand-alone report is associated with greater information over a wide range of social and environmental issues, relatively to the peers in industry and to similar size firms, but it is also associated with more dilution of this CSR information with other irrelevant pieces of information. Furthermore, it is not related to the other two dimensions of 
quality, accuracy and especially managerial orientation, which captures the committed approach to CSR. Moreover, once we consider the two main factors that literature has found to influence voluntary disclosure, such as industry and size, we also note that neither Assurance nor GRI are significantly associated with disclosure quantity ${ }^{13}$.

Although we do find a significant and positive relationship between the use of a stand-alone report and the relative quantity of disclosure, all the other insignificant coefficients are consistent with the view that none of these practices is associated with the enhancement of the quality of disclosure.

Finally, the negative sign of the coefficient of CSR report and density (DENs) potentially suggests an obfuscation strategy, whereas CSR information is "diluted" in many other pieces of not relevant information.

\subsection{Addressing endogeneity concerns}

We are aware that our OLS estimates might suffer from endogeneity bias due to omitted variables. In un-tabulated analyses we conduct several tests to mitigate this concern. First, we re-run our model employing both year and firm fixed-effects to absorb disclosure trends common to all firm in a given year and pick up un-observable heterogeneity across firms and time-invariant selection bias related to firms' disclosure strategy. Second, we also consider an additional vector of observable firm characteristics, such as: ROA, leverage, presence of a CSR committee and membership in a CSR market index, which are likely to be associated with both disclosure and firms' reporting practice (Mallin et al. 2013; Michelon, 2011; Michelon and Parbonetti, 2011, Clarkson et al. 2008). Third, similar to Bonetti et al. (2014), we employ a propensity score matching (PSM) design to minimize the degree of observable heterogeneity between the firms with and without a stand-alone CSR report (Blundell and Costa-Dias, 2009). We select the following variables as determinants of the choice of issuing an environmental report: (1) size, measured as natural logarithm of firm's total

\footnotetext{
${ }^{13}$ Somewhat similarly to the approach undertaken by Rodrigue et al. (2013) we interpret the absence of a significant relationship between CSR practices and CSR disclosure quality as evidence of a symbolic rather than substantive approach to CSR reporting
} 
assets; (2) financial leverage, as the ratio between total debt and total assets; (3) return on investment, computed as the ratio between income before interests and taxes and total assets; (4) CSR performance, measured as the average between the Social and Environmental Pillar scores provided by ASSET4. We include industry fixed effects, to account for systematic differences in the incentives to issue a CSR report across industries. We match each disclosing firm with a nondisclosing firm with the closest estimated propensity score. We allow matching with replacement, as only a relatively small fraction of the firms in our sample does not issue an environmental report. Because of the restrictions imposed by the PSM our sample is significantly reduced to 39 unique firms (28 with a CSR report, 11 without) over the 3 years (total of 117 observations).

The evidence obtained in these additional tests is consistent with the main analysis. While the coefficient between CSR report and the standardised relative quantity index (RQTs) remains significant and of similar magnitude in all specifications, the coefficient between CSR report and standardised density index loses significance in the firm fixed-effect specifications. All other coefficients remain insignificant.

While we do not intend to claim a direction of causality between reporting practices and reporting quality, we also acknowledge that endogeneity might be caused by reverse causality and it could be that reporting practices and quality of disclosure are simultaneously determined. For example, assuming a firm has adopted a committed approach to CSR disclosure, it could be that the decision to assure information or adopt GRI is made once the firm has already reached a certain quality level of CSR information. Thus, we caution readers of this article to infer from our evidence that the adoption of any these CSR reporting practices does not lead to improve CSR disclosure for the firm who adopts it for the first time. Our research design does not allow to make such a claim. All we can say is that on average firms that have stand-alone reports disclose more (but not better) than firms that report CSR information in annual reports and that on average firms that assure CSR information or follow GRI do not disclose more (or better) than firms that do not do so. We do however interpret this non-evidence as supportive of the fact that these practices are generally 
adopted for symbolic reasons rather than according to a substantive approach, because of the multidimensional disclosure measure that is designed to capture the management approach to sustainability.

\subsection{Additional analysis}

We conduct a set of additional analysis on a subset of the disclosures data we gathered: the disclosure of results and outcomes. For these specific disclosures, we further coded whether:

1. the sign of the result or outcome (positive, steady or negative), if stated

2. the reported result was comparable, that is whether there was a benchmark (either in time, space or with respect to a target)

3. the result was expressed in absolute or relative terms.

We then use this coding to build a refined measure of quality, that we label performance completeness index. The performance completeness index is the simple arithmetic mean between the balance index ( $\%$ of results that are signed), the comparability index ( $\%$ of results for which a benchmark is reported) and the precision index (\% of results described in absolute terms). Because this new measure can only be determined for firms that report at least one result disclosure, we estimate a two stage least squares model to control for self-selection (Heckman, 1978) ${ }^{14}$. In the first stage, we model the likelihood that firms report on results on: size, corporate social performance, stakeholder engagement (e.g. Michelon, 2011; measured as an indicator score retrieved from ASSET4), membership in a CSR index (e.g. Michelon, 2011; Michelon and Parbonetti, 2011 indicator retrieved from ASSET4), leverage and ROA (e.g. Clarkson et al. 2008). We further employ year and industry fixed-effects. In the second stage, we estimate the association between the performance completeness index as a function of the three reporting practices and the other control variables. Results show (Table 9) that the performance completeness index is positively and significantly related only to the use of the GRI framework. In a sense, this evidence is not surprising

\footnotetext{
${ }^{14}$ The total number of observations with no results reported is equal to 43 . This appears to be a declining trend as for years 2005, 2006, 2007 - respectively - we have 17, 14, and 12 firms not disclosing any result type of information.
} 
as the semantic dimensions considered to build the index somewhat echo the balance, comparability and accuracy reporting principles for defining the quality of reported information proposed by the GRI itself (G3.1 guidelines). Nevertheless, we also believe this is encouraging (although limited) evidence that companies adopting GRI are not just taking the easy approach of ticking the boxes required by GRI and reporting the various indicators, but they are also following the reporting principles defining the report quality.

Insert Table 9 about here

\section{Discussion and conclusion}

This study theoretically and empirically addresses the symbolic vs. substantive use of three CSR reporting practices by investigating whether the use of a stand-alone report, the use of the GRI guidelines, and the use of assurances about the CSR information are related to the level disclosure quality. We combine different dimensions to measure the quality of CSR disclosure: the content of the information disclosed (what and how much is disclosed), the type of information used to describe and discuss CSR issues (how it is disclosed) and the managerial orientation (the corporate approach to CSR).

In line with critical evaluations of how companies engage in CSR reporting, taken all together our results suggest that the use these CSR-reporting practices is not associated with higher disclosure quality, suggesting that these practices are symbolic, rather than substantive. Companies with stand-alone reports appear to provide more information than companies without, but this information is also diluted within other irrelevant pieces of information. Apparently this dilution of relevant information could be interpreted as a way to conceal CSR information, only portraying the corporation as committed and camouflaging important items of disclosure. The complementary dimensions we consider in our measure of disclosure quality are aimed at capturing whether companies are likely to communicate their effective commitment by recognising and discussing 
environmental and social challenges and problems. Therefore the fact that disclosure quality of the companies adopting the three CSR reporting practices does not differ from disclosure quality of the benchmark group is evidence pointing toward these practices not pursued under an accountability deed. Despite widespread popularity of CSR practices, concerns are to be expressed. With evidence of no significant relation between practices and quality of information communicated to stakeholders, these practices seem to emerge to influence stakeholders' perceptions, engaging in apparent actions that lead key stakeholders to believe that the company is committed to societal requirements.

On a different note, in the additional analysis, we do find a (weak) significant and positive association between the use of the GRI guidelines and the performance completeness disclosure index, a measure that combines balance, comparability and precision of information on results. In as sense, this evidence points out that companies adopting GRI guidelines, and conditional on reporting information on results (typically these are bigger companies, with more active stakeholder engagement processes and belonging to CSR market indexes), are providing more complete information, in line with the reporting quality principles defined by the guidelines. These companies appear not to be simply ticking boxes but rather approaching CSR reporting in a substantive way, which is supporting the focus on performance related disclosure that we put in our quality measure.

This paper makes several contributions to the literature. First, we develop a comprehensive framework with which to measure the quality of social and environmental disclosure. As Hopwood (2009: 437) explains, since "it is possible for some modes of reporting to thicken that veil such as even less is known of the corporation despite the apparent openness of its reporting," it is important to focus also on the semantic properties and the meaning of the information disclosed in order to provide a full picture of corporate disclosure behaviours. Therefore, we rely on recent works on narrative disclosure (Beretta and Bozzolan, 2004, Beretta and Bozzolan, 2008; Chauvey et al., 2013; Patten and Zhao, 2014) to build disclosure indexes that consider explicitly not only the quantity of the information disclosed, but also other dimensions of quality such as density, accuracy 
and managerial orientation. Our results are aligned with those employing traditional measures of disclosure quantity but emphasize a different story when we look at the other dimensions of quality. Second, this research provides evidence that the quality of information disclosed in stand-alone CSR reports is not different from the quality of CSR information reported in the annual report, although it appears that stand-alone reports are used by companies to provide more information. At the same time, we find evidence that such higher amount of information tends to be diluted in longer reports. According to Beretta and Bozzolan (2004), from a user perspective, finding few CSR information among hundreds of pages of reporting makes it difficult to appreciate the commitment to CSR and how the companies is managing CSR activities and issues. Indeed, such behaviour can be interpreted as a concealment technique, where the relevant information is communicated but in a way that makes it difficult for a user to find. All together this evidence is aligned with previous studies that argue that CSR reports are used as impression management rather accountability tools (Cho, Michelon and Patten, 2012).

Third, the study sheds light on effect of the establishment of the GRI framework as the main standard in CSR reporting. Following this standard does not necessarily enhance the accountability process or the information communicated to stakeholders because firms that adopt the framework may appear to disclose broadly without increasing the quality of their disclosure. This evidence is in line with other studies that have found that the mere adoption of guidelines like the GRI does not enhance transparency (Nielsen and Madsen, 2009). Unlike Nielsen and Madsen (2009), however, we do not argue that transparency is granted only through a long-term relationship built on a variety of information channels but that transparency can be improved in the short run by providing stakeholders with information on results and outcomes. Indeed, for the subsample of firms that report this type of information, we find evidence of application of the reporting quality principles of balance, comparability and precision.

Finally, our analysis suggests that the assurance of the CSR reports is not used as a substantive practice, as we find no relationship between such assurance and any dimension of disclosure 
quality. Therefore, assurance could also be seen as a symbolic practice that firms use to influence stakeholder's perceptions of corporate commitment to CSR reporting. This result is in line with the concerns described by Owen (2007): despite the growth in the use of assurance statements, there is still a great deal of ambiguity concerning, for example, its objectives, scope, and procedures. Therefore, as it is currently conceived, this practice "fails to introduce the necessary countervailing power to hold to account and thereby fails to enhance stakeholder accountability" (Owen, 2007: $181)$.

Like all studies, ours is not without limitations. Because the data collection process used here is cumbersome, we employ a relatively small sample, so the extent to which the associations we find hold in other settings cannot be generalized. However, our evidence on the relationship between CSR reporting practices and disclosure suggests that focusing on several dimensions that capture disclosure quality may be critical for future research in social and environmental accounting. We also acknowledge that our measures may not fully capture all the possible and relevant dimensions and measures of the quality of information provided, so the development and use of other dimensions or measures of quality could add to the understanding of CSR reporting practices. Nevertheless, we believe that ours is a good attempt to go beyond traditional measures of disclosure and it provides evidence that assuming disclosure quantity (or worse, the presence of a CSR report) as a good proxy for disclosure quality might mislead interpretation of findings. We focus only on three years of data and one country and we do not know whether evidence from other periods, countries and cultures would be similar. It is worthy to mention that because the UK is considered "an experienced country" (Adams et al. 1998; Beck et al., 2011; Gray et al., 1995; Kolk et al., 2001), the likelihood of finding evidence of a substantive use of these practices in other setting is little. We consider three years in the middle of the 2000-decade, which might be reputed "old data". Nevertheless, this was a decade that witnessed many corporate scandals and companies coming under scrutiny for dubious accounting practices and governance approaches. According to KPMG (2008), worldwide demand for transparency and accountability was "at an all time high". We would 
expect companies more likely to undertake a substantive use of these practices during the aftermath of the transparency and credibility crisis than in other suspicious-less times. Unfortunately, our evidence does not say so.

Finally, and most importantly, our research does not consider what information is material for stakeholders. We leave to future research the investigation of the concept of materiality of CSR information. 


\section{Acknowledgements}

The authors are grateful to two anonymous reviewers, Pietro Bonetti, Giacomo Boesso, Lies Bouten, Carmen Correa-Ruiz, Ericka Costa, Michele Fabrizi, James Hazelton, Matias Laine, Carlos Larrinaga, Andrea Menini, Antonio Parbonetti, Den Patten, Robin Roberts and Michelle Rodrigue for their insightful comments and suggestions. The authors also acknowledge the useful comments received at presentations at the $4^{\text {th }}$ Italian CSEAR Conference (20-21 September 2012, Levico, Italy), and at the $2^{\text {nd }}$ French CSEAR Conference (2-3 May 2013, Montpellier, France), as well as suggestions from the seminar participants at the University of Padova and the University of Trento. Finally, the authors thank Anna Montagnoli and Ana Clara Ventura Paiva for their research assistance. The authors also acknowledge the financial support of the University of Padova (Project $n$. CPDA128717). 


\section{References}

AccountAbility. (2003). AA1000 Assurance Standard. London: AccountAbility.

AccountAbility. (1999). AA1000 Framework. Standard, guidelines and professional qualification. London: AccountAbility.

Adams, C.A., \& Evans, R. (2004). Accountability, completeness, credibility and the audit expectations gap. Journal of Corporate Citizenship, 14, 97-115.

Adams, C.A., Hill, W.Y., \& Roberts, C.B. (1998). Corporate social reporting practices in Western Europe: legitimating corporate behaviour? British Accounting Review, 30(1), $1-21$.

Adams, C.A., \& Kuasirikun, N. (2000). A comparative analysis of corporate reporting on ethical issues by UK and German chemical and pharmaceutical companies. European Accounting Review, 9(1), 53-80.

Adams, C.A. (2004). The ethical, social and environmental reporting - Performance portrayal gap. Accounting, Auditing and Accountability Journal, 17(5), 731-757.

Aerts, W., Cormier, D., \& Magnan, M. (2008). Corporate Environmental Disclosure, Financial Markets and the Media: An International Perspective. Ecological Economics 64(3), 643-659.

Al-Tuwaijri S.A., Christensen, T.E., \& Hughes, K.E. II. (2004). The relations among environmental disclosure, environmental performance, and economic performance: a simultaneous equation approach. Accounting, Organizations and Society, 29(5-6), $447-471$.

Ambec, S., \& Lanoie, P. (2008). Does it Pay to Be Green? A Systematic Overview. Academy of Management Perspectives, 22(4), 45-62.

Amran, A., Lee, S.P., \& Devi, S.S. (2014). The influence of governance structure and strategic corporate social responsibility toward sustainability reporting quality. Business Strategy and the Environment, 23, 217-235

Ashforth, B.E., \& Gibbs, B.W. (1990). The double-edged of organizational legitimation. Organization Science, 1(2), 177-194.

Ball, A., \& Craig, R. (2010). Using neo-institutionalism to advance social and environmental accounting. Critical Perspectives on Accounting, 21, 283-293.

Ball, A., Owen, D.L., \& Gray, R.H. (2000). External transparency or internal capture? The role of third party statements in adding value to corporate environmental reports. Business Strategy and the Environment, 9(1), 1-23.

Bansal, P., \& Clelland, I. (2004). Talking Trash: Legitimacy, Impression Management, and Unsystematic Risk in the Context of the Natural Environment. Academy of Management Journal, 47(1), 93-103.

Bansal, P., \& Hunter, T. (2003). Strategic Explanations for the Early Adoption of ISO 14001. Journal of Business Ethics, 46(3), 289-299.

Basu, K., \& Palazzo, G. (2008). Corporate Social Responsibility: A Process Model of Sensemaking. Academy of Management Review, 33(1), 122-136.

Baum, J.A.C., \& Oliver, C. (1991). Institutional linkages and organizational mortality. Administrative Science Quarterly, 36(2), 187-218. 
Beattie, V., McInnes, B., \& Fearnley, S. (2004). A methodology for analyzing and evaluating narratives in annual reports: a comprehensive descriptive profile and metrics for disclosure quality attributes. Accounting Forum, 28(3), 205-239

Beattie, V., \& Jones, M.J. (1992). The Use and Abuse of Graphs in Annual Reports: Theoretical Framework and Empirical Study. Accounting and Business Research, 22(88), 291-303.

Bebbington, J., Kirk, E.A., \& Larrinaga, C. (2012). The production of normativity: A comparison of reporting regimes. Accounting, Organizations and Society, 37, 78-94.

Beck, A.C., Campbell, D., \& Shrives, P.J. (2010). Content analysis in environmental reporting research: enrichment and rehearsal of the method in a British-German context. The British Accounting Review, 42, 207-222.

Beretta, S., \& Bozzolan, S. (2004). A framework for the analysis of firm risk communication. The International Journal of Accounting, 39, 265-288.

Beretta, S., \& Bozzolan, S. (2008). Quantity vs quality: the case of forward looking disclosure. Journal of Accounting, Auditing and Finance, 3, 333-375.

Berrone, P., Gelabert, L., \& Fosfuri, A. (2009). The impact of symbolic and substantive actions on environmental legitimacy. IESE Working Paper WP 778.

Bird, R., Hall, A.D., Momente, F., \& Reggiani, F. (2007). What Corporate Social Responsibility Activities are Valued by the Market? Journal of Business Ethics, 76(1), 189-206.

Blundell, R., \& Costa Dias, M. (2009). Alternative Approaches to Evaluation in Empirical Microeconomics. Journal of Human Resources, 44(3), 565-640.

Boiral, O. (2013). Sustainability reports as simulacra? A counter-account of A and A+ GRI reports. Accounting Auditing and Accountability Journal, 26(7), 1036-1071.

Bony, K., \& Matten, D. (2011) The relevance of the natural environment for corporate social responsibility research. In P. Bansal, \& A.J. Hoffman (Eds), The Oxford Handbook of Business and the Natural Environment (pp 519-536). Oxford: Oxford University Press.

Bonetti, P., Cho C., Michelon, G., \& Tanaka, Y. (2014). Environmental disclosure and the cost of capital: evidence from the Fukushima nuclear accident, SSRN working paper.

Bouten, L., Everaert, P., Van Liedekerke, L., De Moor, L., \& Christiaens, J. (2011). Corporate social responsibility reporting: A comprehensive picture? Accounting Forum, 35 (3), 187-204.

Brammer, S., Brooks, C., \& Pavelin, S. (2006). Corporate social performance and stocks returns: UK evidence from disaggregate measures. Financial Management, 35(3), 97116.

Brammer, S., \& Millington, A. (2005). Corporate reputation and philanthropy: an empirical analysis. Journal of Business Ethics, 61(1), 29-44.

Brammer, S., \& Pavelin, S. (2004). Voluntary social disclosure by large UK companies. Business Ethics: A European Review, 13(2/3), 86-99.

Brown, J. (2009). Democracy, sustainability and dialogic accounting technologies: Taking pluralism seriously. Critical Perspectives on Accounting, 20(3), 313-342. 
Buhr, N. (2002). A structuration view on the initiation of environmental reports. Critical Perspectives on Accounting, 13, 17-38.

Burrit, R.L., \& Schaltegger, S. (2010). Sustainability accounting and reporting: fad or trend? Accounting, Auditing and Accountability Journal, 23(7), 829-846.

Busch, T. (2011). Organizational Adaptation to Disruptions in the Natural Environment: The Case of Climate Change. Scandinavian Journal of Management, 27, 389-404.

Chauvey, J.N., Giordano-Spring, S., Cho, C., \& Patten, D.M. (2013). The normativity and legitimacy of the CSR disclosure: evidence from France, Working Paper. $36^{\text {th }}$ Annual Congress European Accounting Association, 2-5 May, Paris, France.

Chen, J.C. \& Roberts, R.W. (2010). Toward a more coherent understanding of the organizion-society relationship: a theoretical consideration for social and environmental accounting research. Journal of Business Ethics, 97, 651-665.

Cho, C.H., Guidry, R.P., Hageman, A.M., \& Patten, D.M. (2012). Do actions speak louder than words? An empirical investigation of corporate environmental reputation. Accounting, Organization and Society, 37, 14- 25.

Cho, C.H., Michelon, G., Patten, D.M., \& Roberts, R.W. (2013). CSR report assurance in the United States: an empirical investigation of demand and stakeholder benefits. Working paper. $36^{\text {th }}$ Annual Congress European Accounting Association, 2-5 May, Paris, France.

Cho, C.H., Michelon, G., Patten, D.M., \& Roberts, R.W. (2012). The market valuation of social and environmental disclosure. Working paper. 24th CSEAR International Congress on Social and Environmental Accounting Research, 3-5 Sept. St. Andrews, UK.

Cho, C.H., Michelon, G., Patten, D.M. (2012). Impression management in sustainability reports: an empirical investigation of the use of graphs. Accounting and the Public Interest, 12, 16-37.

Cho, C.H., \& Patten, D.M. (2007). The role of environmental disclosures as tools of legitimacy: A research note. Accounting, Organizations and Society, 32(7/8), 639-647.

Cho, C.H., Roberts, R.W., \& Patten, D.M. (2010). The language of US corporate environmental disclosure. Accounting, Organizations and Society, 35(4), 431-443.

Cho, C.H., Patten, D.M. \& Roberts, R.W. (2011). Corporate Environmental Financial Reporting and Financial Markets. in P. Bansal, \& A.J. Hoffman (Eds), The Oxford Handbook of Business and the Natural Environment (pp 519-536). Oxford: Oxford University Press.

Choi, J. (1999). An investigation of the initial voluntary environmental disclosures made in Korean semi-annual financial reports. Pacific Accounting Review, 11(1), 75-102.

Clarke, T. (2007). The materiality of sustainability. In S. Benn, \& D. Dunphy (Eds), Corporate governance and sustainability. Challenges for theory and practice. (pp. 219-251). Abingdon, Oxon: Routledge.

Clarkson, P.M., Li, Y., Richardson, G.D., \& Vasvari, F.P. (2008). Revisiting the relation between environmental performance and environmental disclosure: An empirical analysis. Accounting, Organizations and Society, 33(4/5), 303-327.

Colbert, B.A., \& Kurucz, E.C. (2007). Three Conceptions of Triple Bottom Line Business Sustainability and the Role for HRM. Human Resource Planning, 30(1), 21-29. 
Cooper, S., Owen, D. (2007). Corporate social reporting and stakeholder accountability: the missing link. Accounting, Organizations and Society, 32, 649-67.

Cormier, D., \& Magnan, M. (2007). The revisited contribution of environmental reporting to investors' valuation of a firm's earnings: An international perspective. Ecological Economics, 62 (3-4), 613-626.

Cormier, D., \& Magnan, M. (2003). Environmental reporting management: A continental European perspective. Journal of Accounting and Public Policy, 22(1), 43-62.

Cormier, D., Magnan, M., \& Van Velthoven, B. (2005). Environmental Disclosure Quality: Do Firms Respond to Economic Incentives, Public Pressures, or Institutional Conditions. European Accounting Review, 14(1), 1-37.

Dando, N., \& Swift, T. (2003). Transparency and assurance: minding the credibility gap. Journal of Business Ethics, 44 (2/3), 195 - 200.

Dawkins, C., \& Fraas, J. (2011). Coming Clean: The Impact of Environmental Performance and Visibility on Corporate Climate Change Disclosure. Journal of Business Ethics, 100(2), 303-322.

De Villers, C., \& Alexander, D., (2014). The institutionalization of Corporate social responsibility reporting. The British Accounting Review, DOI: 10.1016/j.bar.2014.03.001

Deephouse, D. L. (1996). Does isomorphism legitimate? Academy of Management Journal, 39, 1024-39.

Deephouse, D.L., \& Carter, S.M. (2005). An Examination of Differences between Organizational Legitimacy and Organizational Reputation. Journal of Management Studies, 42(2), 329-360.

Dhaliwal, D.S., Li, O.Z., Tsang, A., \& Yang, Y.G. (2014). Corporate social responsibility disclosure and the cost of equity capital: the roles of stakeholder orientation and financial transparency. Journal of Accounting and Public Policy, DOI: 10.1016/j.jaccpubpol.2014.04.006

Dhaliwal, D.S., Li, O.Z., Tsang, A., \& Yang, G.Y. (2011). Voluntary nonfinancial disclosure and the cost of equity capital: the initiation of corporate social responsibility reporting. The Accounting Review, 86(1), 59-100.

Dhaliwal, D.S., Radhakrishnan, S., Tsang, A., \& Yang, Y.G. (2012). Nonfinancial disclosure and analyst forecast accuracy: International evidence on corporate social responsibility disclosure. The Accounting Review, 87(3), 723-759.

DiMaggio, P. J. \& Powell, W. (1983). The iron cage revisited. Institutional isomorphism and collective rationality in organizational fields. American Sociological Review, 48, $147-60$.

Doane, D. (2000). Corporate Spin: The Troubled Teenage Years of Social Reporting. London: New Economics Foundation.

Doh, J.P., Howton, S.D., Howton, S.W., \& Siegel, D.S. (2010). Does the Market Respond to an Endorsement of Social Responsibility? The Role of Institutions, Information, and Legitimacy. Journal of Management, 36(10), 1461-1485.

Dowling, J., \& Pfeffer, J. (1975). Organizational legitimacy: social values and organizational behaviour. Pacific Sociological Review, 18(1), 122-136. 
Edgley, C.R., Jones, M.J., \& Solomon, J.F. (2010). Stakeholder inclusivity in social and environmental report assurance. Accounting, Auditing and Accountability Journal, 23(4), 532-557.

Elsbach, K.D. (1994). Managing organizational legitimacy in the California cattle industry: the construction and effectiveness of verbal accounts. Administrative Science Quarterly, 39(1), 57-88.

Etzion, D., \& Ferraro, F. (2010). The role of analogy in the institutionalization of sustainability reporting. Organization Science, 21(5), 1092-1107.

Fédération des Experts Comptables Européens (FEE). (2002). Providing assurance on sustainability reports. Brussels: Fedération des Experts Comptables Européens.

Forbes, L.C., \& Jermier, J.M. (2011). The new corporate environmentalism and the symbolic management of organizational culture. In P. Bansal, \& Hoffman A.J. (Eds), The Oxford Handbook of Business and the Natural Environment (pp 519-536). Oxford: Oxford University Press.

Fowler, S.J., \& Hope, C. (2007). A Critical Review of Sustainable Business Indices and their Impact. Journal of Business Ethics, 76(3), 243-252.

Freedman, M, \& Patten, D.M. (2004). Evidence on the pernicious effect of financial report environmental disclosure. Accounting Forum, 28(1), 27-41.

Freedman, M, \& Wasley, C. (1990). The association between environmental performance and environmental disclosure in annual reports and 10Ks. Advances in Public Interest Accounting, 2, 183-93.

Freedman, M. (1998). Social disclosure, attestation and the single audit act. Critical Perspectives on Accounting, 9(2), 201- 204.

Gamerschlag, R., Moller, K., \& Verbeeten, F. (2011). Determinants of voluntary CSR disclosure: empirical evidence from Germany. Review of Management Sciences, 5, 233-262.

Global Reporting Initiative (GRI). (2012). Sustainability reporting guidelines (G3 guidelines). $\quad$ Retrieved on May, from https://www.globalreporting.org/reporting/G3andG3-1/Pages/default.aspx; 2006.

Global Reporting Initiative (GRI). (2002). Sustainability reporting guidelines on economic, environmental and social performance. Amsterdam: Global Reporting Initiative.

Gray, R., \& Herremans, I.M. (2011). Sustainability and social responsibility reporting and the emergence of the external social audits: the struggle for accountability? In P. Bansal, \& Hoffman A.J. (Eds), The Oxford Handbook of Business and the Natural Environment (pp 519-536). Oxford: Oxford University Press.

Gray, R., Kouhy, R., \& Lavers, S. (1995). Corporate social and environmental reporting: a review of the literature and a longitudinal study of UK disclosure. Accounting, Auditing and Accountability Journal, 8(2), 47-77.

Gray, R., Owen, D., \& Maunders, K. (1988). Corporate social reporting: emerging trends in accountability and the social contract. Accounting, Auditing and Accountability Journal, 1(1), 6-20.

Gray, R. (2002). The social accounting project and accounting organizations and society privileging engagement, imaginings, new accountings and pragmatism over critique? Accounting, Organizations and Society, 27, 687-708. 
Gray, R. (2010). Is accounting for sustainability actually accounting for sustainability. . . and how would we know? An exploration of narratives of organisations and the planet. Accounting, Organizations and Society, 35, 47-62.

Hackston, D., Milne, M.J. (2006). Some determinants of social and environmental disclosures in New Zealand companies. Accounting, Auditing and Accountability Journal, 9(1), 77-108.

Hannan, M.T., \& Freeman, J. (1989). Organizational Ecology. Cambridge, MA Harvard University Press.

Heckman, J. (1978). Dummy endogenous variables in a simultaneous equation system. Econometrica, 46(4), 931-959.

Henry, J.F., \& Journeault, M. (2010). Eco-control: the influence of management control systems on environmental and economic performance. Accounting Organizations and Society, 35, 63-80.

Hoffman, H., Busse, C., Bode, C., \& Henke, M. (2014). Sustainability-related supply chain risks: conceptualization and management. Business Strategy and the Environment, 23, 160-172.

Hogner, R.H. (1982). Corporate Social Reporting: Eight Decades of Development at U.S. Steel. Research in Corporate Performance and Policy, 4: 243-250.

Hopwood, A.G. (2009). Accounting and the environment. Accounting, Organizations and Society, 34,433-439.

Hughes, S.B., Anderson, A., \& Golden, S. (2001). Corporate environmental disclosures: are they useful in determining environmental performance? Journal of Accounting and Public Policy, 20(3), 217-240.

Husillos, J., Larrinaga, C., \& Álvarez, M. J. (2011). The emergence of triple bottom line reporting in Spain. Revista Española de Financiación y Contabilidad, 60(150), $195-$ 219.

Jaggi, B., \& Freedman, M. (1982). An Analysis of the Informational Content of Pollution Disclosures. The Financial Review, 19(5),142-152.

Janis, I.L., \& Fadner, R. (1965). The Coefficient of Imbalance. In H. Lasswell, N. Leites, \& Associates (Eds.), Language of politics (pp. 153-169). Cambridge, MA: MIT Press.

Joseph, G. (2012). Ambiguous but tethered: an accounting basis for sustainability reporting. Critical Perspectives on Accounting, 23, 93- 106.

Kent, P., \& Zunker, T. (2013). Attaining legitimacy by employee information in annual reports. Accounting Auditing and Accountability Journal, 26(7), 1072-1106.

Kim, E.H., \& Lyon, T.P. (2011). When Does Institutional Activists Increase Shareholder Value? The Carbon Disclosure Project. The BE Journal of Economic Analysis and Policy, 11(1), 93-121.

King, A.A., \& Lenox, MJ. (2000). Industry self-regulation without sanctions: the chemical industry's responsible care program. Academy of Management Journal, 43(4), 698716.

Kolk, .A, Walhain, S., \& van der Wateringen, S. 2001. Environmental reporting by the Fortune Global 250: Exploring the influence of nationality and sector. Business Strategy and the Environment, 10, 15-28. 
Kolk A., Levy, D., \& Pinkse, J. (2008). Corporate responses in an emerging climate regime: the institutionalization and commensuration of carbon disclosure. European Accounting Review, 17(4), 719-745.

KPMG. (2011). KPMG International Survey of Corporate Responsibility Reporting. KPMG International Cooperative.

KPMG. (2013). KPMG International Survey of Corporate Responsibility Reporting. KPMG International Cooperative.

Krippendorff, K. (2004). Reliability in content analysis. 30, 411-433.

Larrinaga, C. (2014). The institutionalization of sustainability reporting. Working paper presented at the 50th BAFA (British Accounting and Finance Association) Conference, London, England, 14-16 April

Lewis, L., \& Unerman, J. (1999). Ethical relativism: a reason for differences in corporate social reporting? Critical Perspective on Accounting, 10, 521-547.

Mahoney, L.S., Thorne, L., Cecil, L., \& LaGore, W. (2013). A research note on standalone corporate social responsibility reports: Signaling or greenwashing? Critical Perspectives on Accounting, 24(4-5), 350-359.

Mallin, C.A., Michelon G., \& Raggi, D. (2013). Monitoring intensity and stakeholders' orientation: how does governance affect social and environmental disclosure?. Journal of Business Ethics, 114(1), 29-43.

Malsh, B. (2013). Politicizing the expertise of the accounting industry in the realm of corporate social responsibility. Accounting, Organizations and Society, 38, 149-168

Manetti G., \& Beccatti, L. (2009). Assurance Services for sustainability reports: standards and empirical evidence. Journal of Business Ethics, 87, 289-298

Margolis, J.D., \& Walsh, J.P. (2003). Misery Loves Companies: Rethinking Social Initiatives by Business. Administrative Science Quarterly, 48(4), 655-689.

Mathews, M.R. (1993). Socially responsible accounting. London: Chapman Hall.

McGuire, J., Sundgren, A., \& Schneeweis, T. (1988). Corporate Social Responsibility and Firm Financial Performance. Academy of Management Journal, 31(4), 854-872.

Merkl-Davies, D.M., \& Brennan, N.M. (2007). Discretionary disclosure strategies incorporate narratives: incremental information or impression management? Journal of Accounting Literature, 26, 116-196.

Meyer, J.W. \& Rowan, B. (1977). Institutionalized Organizations: Formal Structure as Myth and Ceremony. American Journal of Sociology, 83, 340-63.

Michelon, G., (2011). Sustainability disclosure and reputation: a comparative study. Corporate Reputation Review, 14(2), 79-96

Michelon, G., \& Parbonetti, A. (2012). The effect of corporate governance on sustainability disclosure. Journal of Management and Governance, 16, 477-509.

Mills, D., \& Gardner, M. (1984). Financial Profiles and the Disclosure of Expenditures for Socially Responsible Purposes. Journal of Research, 12 (December), 407-424.

Milne, M., \& Gray, R. (2013). W(h)ither Ecology? The Triple Bottom Line, the Global Reporting Initiative, and Corporate Sustainability Reporting. Journal of Business Ethics, 118(1), 13-29. 
Milne, M., \& Gray, R. (2007). Future prospects for sustainability reporting. In: J. Unerman, J. Bebbington, \& B. O’Dwyer (Eds.) Sustainability accounting and accountability (pp. 184-207). London: Routledge.

Milne, M. (2002). Positive accounting theory, political costs and social disclosure analyses: a critical look. Critical Perspectives on Accounting, 13, 369-395.

Moneva, J., Archel, P., \& Correa, C. (2006). GRI and the camouflaging of corporate unsustainability. Accounting Forum, 30, 121-137.

Moser, D.V. \& Martin, P.R. (2012). A broader perspective on corporate social responsibility research in accounting. The Accounting Review, 87(2), 797-806.

Neu, D., Warsame, H., \& Pedwell, K. (1998). Managing public impressions: environmental disclosures in annual reports. Accounting, Organizations and Society, 23(3), 265-82.

Nielsen, C., \& Madsen, M.T. (2009). Discourses of transparency in the intellectual capital reporting debate: Moving from generic reporting models to management defined information. Critical Perspectives on Accounting, 20(7), 847-854.

O’Dwyer, B., \& Owen, D. (2005). Assurance statement practice in environmental, social and sustainability reporting: A critical evaluation. British Accounting Review, 37(2), $205-229$.

Orlitzky, M., Schmidt, F.L., \& Rynes, S. L. (2003). Corporate social and financial performance: A meta-analysis. Organization Studies, 24(3), 403-441.

Owen, D.L. (2007) Assurance practice in sustainability reporting. In: J. Unerman, J. Bebbington, \& B. O’Dwyer (Eds.) Sustainability accounting and accountability (pp. 168-183). London: Routledge.

Owen, D.L., Swift, T.A., Humphrey, C., \& Bowerman, M. (2000). The new social audits: accountability managerial capture or the agenda of social champions? European Accounting Review, 9 (1), 81-98.

Patten, D.M., \& Zhao, N. (2014). Stand-alone reporting by U.S. retail companies. Accounting Forum, 38(2), 132-144.

Patten, D.M. (1991). Exposure, legitimacy and social disclosure. Journal of Accounting and Public Policy, 10(4), 297-308.

Patten, D.M. (1992). Intra-industry environmental disclosures in response to the Alaskan oil spill: A note on legitimacy theory. Accounting, Organizations and Society, 17(5), 471-475.

Patten, D.M. (2005). The accuracy of financial report projections of future environmental capital expenditures: A research note. Accounting, Organizations and Society, 30, 457468.

Patten, D.M. (2002). The relation between environmental performance and environmental disclosure: A research note. Accounting, Organizations and Society, 27(8), 763-773.

Reid, E.M., \& Toffel, M.W. (2009). Responding to Public and Private Politics: Corporate Disclosure of Climate Change Strategies. Strategic Management Journal, 29(10), 1027-1055.

Rodrigue, M., Magnan, M., Cho, C.H. (2013). Is environmental governance substantive or symbolic? An empirical investigation Journal of Business Ethics, 114(1), 107-129.

Schultz, M., Mouritsen, J., \& Gabrielsen, G. (2001). Sticky Reputation: Analyzing a 
Ranking System. Corporate Reputation Review, 4(1), 24-41.

Sharma, S. (2000). Managerial interpretations and organizational context as predictors of corporate choice of environmental strategy. Academy of Management Journal, 43(4), 681-697

Siegel, D.S. (2009). Green Management Matters Only If It Yields More Green: An Economic/Strategic Perspective. The Academy of Management Perspective, 23(2), 516.

Spence C. (2009). Social accounting's emancipatory potential: a Gramscian critique. Critical Perspectives on Accounting, 20, 205-227.

Suchman, M.C. (1995). Managing legitimacy: Strategic and institutional approaches. Academy of Management Review, 20(3), 571-610.

Sutton, S.G., \& Arnold, V. (1998). Towards a framework for a corporate single audit: meeting financial statement users' needs. Critical Perspectives on Accounting, 9, 177191.

Swift, T., \& Dando, N. (2002). From methods to ideologies: closing the assurance expectations gap in social and ethical accounting auditing and reporting. Journal of Corporate Citizenship, 8, 81-90.

Thomson, I., \& Bebbington, J. (2005). Social and environmental reporting in the UK: a pedagogic evaluation. Critical Perspectives on Accounting, 16(5), 507-533.

Thorne, L. Mahoney, L.S. \& Manetti, G. (2014). Motivations for issuing standalone CSR reports: a survey of Canadian firms. Accounting Auditing and Accountability Journal, $27(4), 686-714$

Tinker, T., Lehman, C., \& Neimark, M. (1991). Falling down the hole in the middle of the road: political quietism in corporate social reporting. Accounting Auditing and Accountability Journal, 4(2), 28-54.

UNEP/SustainAbility reporting guidelines (1996). Engaging stakeholders: the benchmark survey. London: UNEP/SustainAbility

Unerman, J., Bebbington, J., \& O'Dwyer, B. (2007). Introduction to sustainability accounting and accountability. In: J. Unerman, J. Bebbington, \& B. O'Dwyer (Eds.) Sustainability accounting and accountability (pp. 1-16). London: Routledge.

Wiseman, J., (1982). An evaluation of environmental disclosures made in corporate annual reports. Accounting, Organizations and Society, 7(1): 53-63.

Wong, R., \& Millington, A. (2014). Corporate social disclosures: a user perspective on assurance. Accounting, Auditing and Accountability Journal, 27(5), 863 - 887

Zorio, A., Garcia-Benau, M.A., \& Sierra, L. (2013). Sustainability development and the quality of assurance reports: empirical evidence. Business Strategy and the Environment, 22, 484-500 